Afric

ArXiv

Article title: Higher Education in Ethiopia: Recent Developments and Challenges

Authors: Addisalem Yallew[1]

Affiliations: University of the Western Cape[1]

Orcid ids: 0000-0001-5275-6430[1]

Contact e-mail: 3743398@myuwc.ac.za

License information: This work has been published open access under Creative Commons Attribution License http://creativecommons.org/licenses/by/4.0/, which permits unrestricted use, distribution, and reproduction in any medium, provided the original work is properly cited. Conditions, terms of use and publishing policy can be found at https://www.scienceopen.com/.

Preprint statement: This article is a preprint and has not been peer-reviewed, under consideration and submitted to AfricArXiv Preprints for open peer review.

DOI: $10.14293 / 111.000 / 000009 . v 1$

Preprint first posted online: 24 July 2020

Keywords: Higher education, enrolment, staff development, funding, research, graduate studies, internationalization, continuing education, Ethiopia 


\title{
HIGHER EDUCATION IN ETHIOPIA: RECENT DEVELOPMENTS AND CHALLENGES
}

\author{
Addisalem Tebikew Yallew ${ }^{1}$
}

\section{INTRODUCTION}

Some scholars claim higher learning in Ethiopia is as old as the Obelisks of Axum and goes back to the monastic traditions of the Orthodox Church and thus dates as far back as 300 AD (Abebe, 1995; Kebede, 2010; Teferra, 2017; Teferra \& Altbach, 2004; Saint, 2004; Wagaw, 1990). Church education aimed not only at training priests and monks but also civil servants such as judges, governors, scribes, treasurers, and general administrators (Wagaw, 1979). Islam, which took root in Ethiopia in the 7th century, also introduced the two-tier Quranic system of education with distinct basic and higher levels (Abebe, 1995; Asgedom \& Hagos, 2016; Seyoum, 1995).

However, higher education in its contemporary form is commonly traced back to the opening of the Addis Ababa University College in 1950 (Wagaw, 1990; Asgedom \& Hagos, 2016). Between the 1950 s and the last decade of the $20^{\text {th }}$ century, the country had only two public higher education institutions and no private higher education providers (Yirdaw, 2016). However, expansion initiatives that started towards the last decade of the 20th century increased the number of state-run universities to eight by 2002 (Bishaw \& Melesse, 2017). This trend continued during the past two decades, and it can be argued that the outstanding features of contemporary Ethiopian higher education are strong state-led expansion and rapid reform. At present, Ethiopian universities enroll students who have completed two-year preparatory classes, in grades 11 and 12 with: three to six-year undergraduate programs, two-year master's

\footnotetext{
${ }^{1 \rightarrow 33743398 @ \text { myuwc.ac.za / addisworld@gmail.com }}$ Institute of Post-School Studies (IPSS) 
programs, and four-to-five years of PhD-level studies in their regular programs (Ayalew 2017; MOE, 2017).

In the past decade, the focus of this paper, remarkable gains have been made in increasing access to higher education with the opening of two new universities per year on average. According to the Ethiopian Education Strategy Centre (2015), the country plans to increase the total number of public universities to 44 by 2020 . To further illustrate the expansion, only ten years ago, the Ethiopian Ministry of Education (MOE) stated that the country had 319,217 students enrolled in its higher education system in 2007-2008. In 2017 already, the country enrolled more than 800,000 students in 37 public and 124 accredited private higher education institutions in both undergraduate and graduate programs (MOE, 2017). The $2.4 \%$ attendance of the appropriate age cohort reported for the country by The World Bank in 2008 has also increased by approximately 120\% since (Gulliksen \& Audensen, 2013). The attention the expanding higher education sector in Ethiopia has been receiving can also be demonstrated in terms of funding: The Ethiopian government invests more than $40 \%$ of its education budget on higher education (UNESCO, 2015; Raynor \& Ashcroft, 2012). Despite this expansion, it is worth noting that the country's higher education system is still considered elitist by global comparison, for the current gross enrolment ratio which stands at a little over $8 \%$ (UNESCO, 2015) has not reached the minimum 15\% gross enrolment margin theorized by Trow (2007).

The initiative to reform higher education and research seems to be driven by tertiary education's potential contribution to economic development in the framework of the Agricultural Development Led Industrialization (ADLI) development strategy adopted, which is supposed to enable the country to join the league of middle-income countries by 2025 (FDRE, 2012; MOE, 2010; Akalu, 2014; O'Keeffe, 2016). The reform measures are also based on the five-year Growth and Transformation Plans (GTPs) implemented in the country. 
Management tools like Balanced Score Card (BPR), Business Process Re-engineering (BSC), the Japanese inspired model Kaizen, and more recently, the British inspired Deliverology model were introduced into the higher education system by the government in different periods to bring about better institutional efficiency, governance, and leadership. Though the state seems to be the most potent driver of such measures, international agencies, especially The World Bank, have had considerable influence in setting policy and reform agendas and financing reform initiatives (Molla, 2014; Woldegiyorgis, 2014). However, the success of the above reform measures in transforming higher education in the country has not been assessed favorably by university internal stakeholders (Ayalew, 2017; Asgedom \& Hagos, 2016; Mehari, 2010; Asmamaw, 2012). Lack of ownership and support of the majority of academic staff, lack of commitment and leadership qualities by managers to implement the reforms as transformative leaders, the absence of deliberation and communication, and lack of decentralization of power and decision-making have been identified as some of the reasons hindering the success of the reform measures (Asgedom \& Hagos, 2016).

Structure-wise, The Ethiopian Ministry of Education (MOE) is the most authoritative body regulating and managing reform in higher education (Yizengaw, 2003). The Ministry has the final say in appointing university presidents, approving university board members, and students' admission to universities. The Ministry is also the most powerful body in giving specific guidance to universities through directives and policy documents; the most influential documents are the 1994 'Education and Training Policy' of the Transitional Government of Ethiopia (TGE) Higher Education Proclamations of 2003 and 2009. The Education Sector Development Programs or action plans (ESDPs), currently at their fifth stage of implementation, are also major documents giving public universities guidance. In the face of this massive expansion, the two national autonomous buffer organizations, The Higher Education Relevance and Quality Assurance Agency (HERQAA) and the Education Strategy 
Centre (ESC), also play a role in terms of assessing the relevance, conducting quality audits, accreditation of (mainly private) higher education providers, and promoting leadership capacity development and higher education research (Asgedom \& Hagos, 2016; Bishaw \& Melesse, 2017).

In addition to university boards, Ethiopian higher education institutions are led by a president and vice presidents. For instance, Addis Ababa University currently has four vice presidents: academic, administration and student services, research and technology transfer, and institutional development (Ayalew, 2017). The Managing Council, the University Council, and a University Senate also serve as advisory organs to the university president. The latest Higher Education Proclamation (FDRE, 2009) states that; while the Managing Council advises the president on strategic issues, the University Council advises planning, budgeting, organizational structuring, and academic programs. The Senate serves as the leading body for all university academic affairs (Ayalew, 2017). Ethiopian universities are further organized into colleges, schools, and institutes with departments. Accountable to the academic vice president through their respective deans or directors, those institutional organization units have Academic Commissions as their highest governance body. An academic commission comprises the dean, associate and assistant deans, department heads, faculty, and student representatives. Academic commissions are responsible for determining programs of study, educational standards, and all academic matters concerning student and faculty (Ayalew, 2017).

Despite this massive expansion, diversification, and reform, Ethiopian higher education does not, however, seem to be accompanied by differentiation like the rest of Africa (Ng'ethe et al., 2008; Woldegiyorgis, 2015). Partly attributable to the state's coercive power and the general policy directives it provides, the expanding Ethiopian higher education system demonstrates higher isomorphism than differentiation. Many of the country's public 
universities can be regarded as more similar than differentiated in that they focus on teaching - undergraduates in particular - rather than on research and graduate education. Research is currently in need to be diversified through differentiation and promoting graduate education, especially considering that many of the country's public universities aspire to become researchintensive (Woldegiyorgis, 2015; Teferra, 2007). However, it is worth noting that the system seems to be horizontally differentiated regarding having public and private providers. Limited initiatives towards differentiation also include measures that have been taken to establish Institutes of Technology (IOTs) in eight public universities and separate universities of science and technology jointly overseen by the Ministry of Education and the Ministry of Science and Technology.

In the subsequent sections, current trends, and challenges related to enrolment, staffing, funding, research output, continuing education, internationalization, and graduate studies are discussed in consulting secondary data from previous research and literature. As an educator in a public university in Ethiopia for close to ten years, the author's own experience also informed the article.

\section{ENROLMENT}

As stated above, in the past two decades, Ethiopian higher education has been expanding, especially in enrollment. The gross enrolment rate of the eligible age cohort which displayed limited growth of $0.6 \%$ on average between 1970 and 2000 (Saint, 2004), has risen to more than $8 \%$ since the turn of the $21^{\text {st }}$ century; and, currently, close to 800,000 undergraduate students are enrolled in Ethiopian universities in regular, evening, summer and distance programs. More than $80 \%$ of undergraduate students are currently enrolled in state-run universities, while private higher education providers account for $15 \%$ of the student intake for the 2015-2016 academic year (MOE, 2017). The expansion of the country's higher 
education system has led to the expansion of postgraduate enrolments, too, the phenomenon of which will be discussed below in the graduate education section.

\section{Figure 1. Gross enrolment ratio in Ethiopian higher education (2000-2014)}

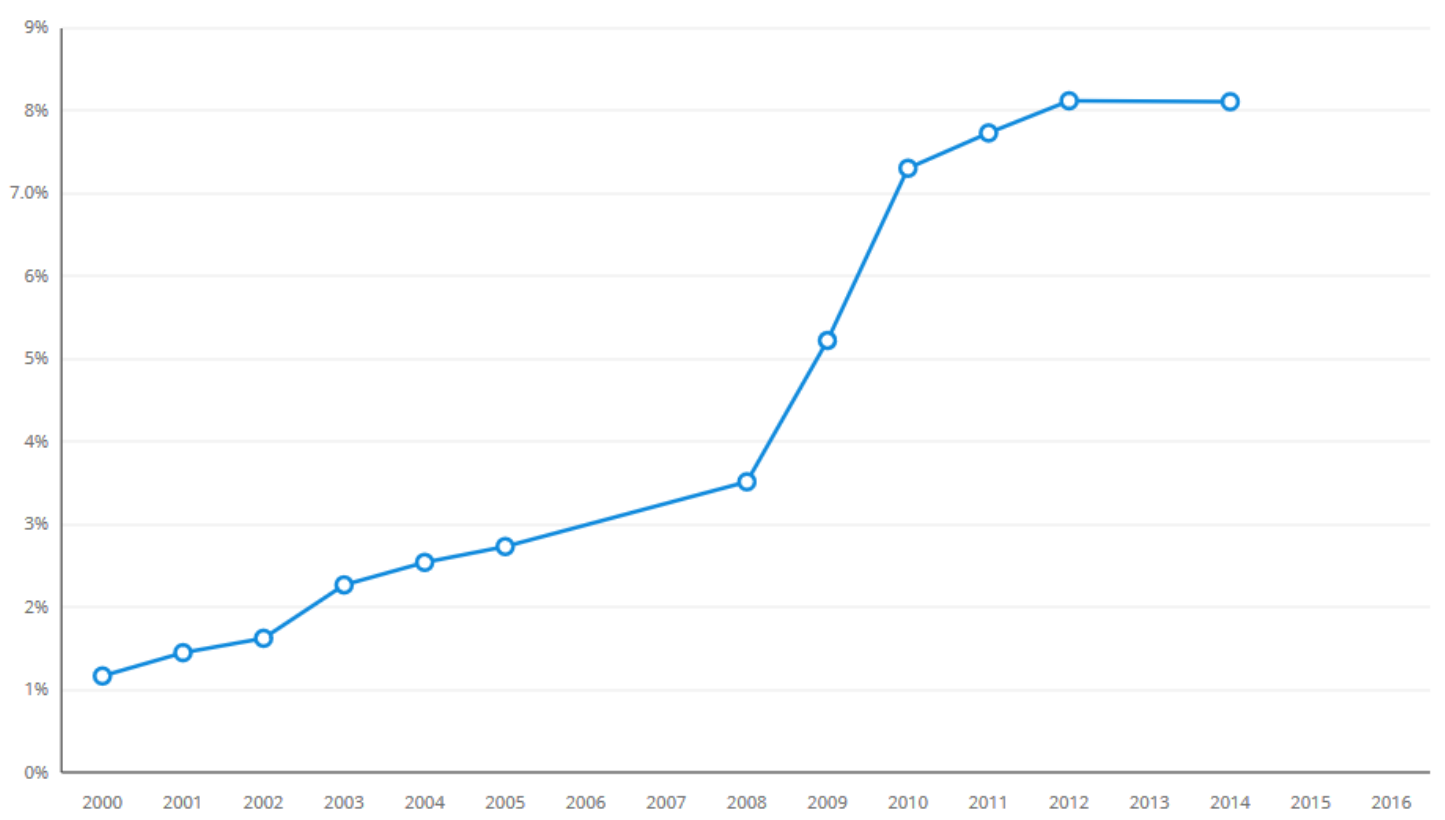

Source: UNESCO Institute of Statistics (UIS) (2018)

This considerable expansion seems to pose some challenges, however. Issues related to the negative implications of so-called massification projects on the overall quality of education have been raised by several researchers (Van Deuren et al., 2016; O'Keeffe, 2016; Reisberg, \& Rumbley, 2015; Akalu, 2014; Semela, 2011; Tessema, 2009). Like in other African higher education systems, the access versus quality conundrum is one of the complex challenges Ethiopian higher education need to address, for "Improving academic quality and expanding access do not lie on the same (if not necessarily opposite) trajectories, owing largely to the dynamics of resources" (Teferra, 2013, p. 3). To address these challenges, some scholars (e.g., Semela, 2011a; Waweru \& Abate, 2013) have argued for a slowdown of this trend to focus on qualitative concerns like equity and quality of education and research. It has to be noted, 
however, that still more expansion efforts need to take place to increase access as the current student gross enrolment figure in Ethiopia, which stands at $8.13 \%$, is less than the gross enrolment ratio of both sub-Saharan Africa and low-income countries and countries(UNESCO, 2017). On the other hand, $h$ concerns have been expressed on the increased enrolment of students which fails to take into account the limited human and other resources of universities leading to overburdening academic staff, implying heavy teaching workload and hence repercussions on quality education (Ayalew, 2017; Akalu, 2014; Ashcroft, 2010; Tessema, 2009). Besides, necessary infrastructure such as furniture, ICT, laboratory chemicals, and library resources were also in short supply in Ethiopian universities (Akalu, 2014; Ayalew, 2017). The massive enrolment figures are also critiqued for producing graduates lacking skills needed by the labor market (Saint, 2004; Ayalew 2017; Bishaw \& Melesse, 2017). The increased enrollment initiatives generally focus on recruiting $70 \%$ of students to STEM fields while the remaining 30\% for social sciences and humanities (MOE, 2010). This policy has also been questioned considering the demand for and availability of jobs in the natural sciences, and engineering is already saturated (Tamrat, 2018; Woldegiyorgis, 2012).

Having a more equitable higher education system while also focusing on providing much-needed access has also been another significant challenge for contemporary Ethiopian higher education. Though creating a more equitable system has been one of the major concerns for higher education policy and reform in Ethiopian higher education (Molla, 2014; FDRE 2003, 2009), there have been concerns that goals set for creating such a higher education system are not being met (Sidelil, 2015; Molla \& Gale, 2015; Molla, 2014). According to Molla \& Gale (2015), higher education in Ethiopia is characterized by the under-representation of especially women, geo-politically marginalized ethnic groups, people from low socioeconomic backgrounds and people from peripheral regions and rural areas. Sidelil (2015, p. 58) argues, "Although there are some strong political and legal basis, as well as policy 
provisions, the issue of equity in higher education in Ethiopia is addressed in a fragmented and insufficient way." For instance, research points out to significant gender disparities in higher education participation and completion in the country (MOE, 2017; Molla, 2014; Sidelil, 2015; Yizengaw, 2007).

Despite the recent gains widening access to female students, current female student enrolment which has more than doubled compared to the $16 \%$ gross enrolment at the turn of the century (Bishaw \& Melesse, 2017), still stands at 34.14\% at the undergraduate and at 23.1\% at the postgraduate levels (MOE, 2017). Ethiopia currently ranks 136th in terms of the global gender parity index in tertiary education (World Economic Forum, 2017). The challenges of creating an equitable higher education system also surface when we consider the considerable rural-urban enrolment gap (Molla \& Gale, 2015; Abiy et al., 2014). For instance, Lestrade (2012) states that more than $70 \%$ of Ethiopian higher education students come from families in the top income quartile and from urban areas. This is a considerable disparity, especially when considering in the same year, i.e., 2012, the country's urban population accounted for only $18 \%$ of the mostly rural country (World Bank, 2018). Students with disabilities also seem to be left out of the 'massification' project (Tamrat, 2018; Arefaine, 2008; Addis Ababa University, 2014). According to Tamrat (2018), though the number of students with disabilities in Ethiopian higher education institutions has risen from 398 in 2009-10 to more than 1000 in 2015, the enrolment ratio number is still low, considering the percentage of the population with disabilities in the general population, and the limited number of disabled students undertake their studies in unaccommodating environments where most higher education institutions are ill-prepared to provide the necessary provisions. In addition, a study conducted by Addis Ababa University with data from 10 universities in the country reiterates the following issues disabled students face in Ethiopian universities: problems related to placement decisions, lack of sufficient orientations upon entry to universities, absences of assistive technologies, rigid 
curricula, absence of diversity of management strategies, lack of preparedness on the part of university leadership, limitations in service provisions and attitudinal problems towards disability (Addis Ababa University, 2014).

\section{ACADEMIC STAFF}

To cater to the demands of the expanding higher education sector, the number of academic staff members in Ethiopian universities has risen from 20,822 in 2012 to 30,496 in 2016, a 46.5\% increase over four years (MOE, 2017).

Figure 2. Trends in academic staff development (2011- 2016)

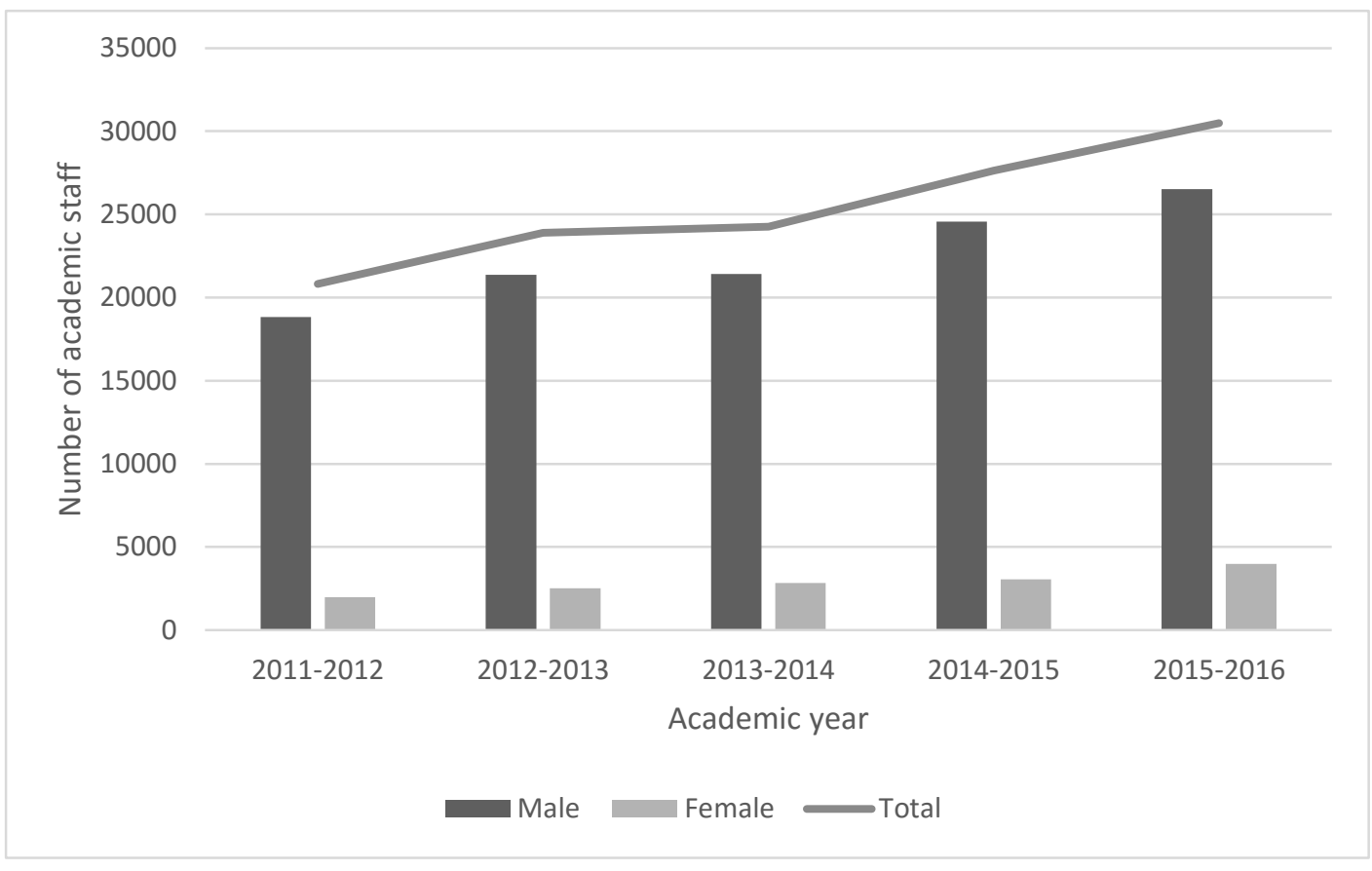

Source: Ethiopian Ministry of Education (MOE) (2017)

In terms of qualifications, statistics from the Ethiopian Ministry of Education for 20152016 indicate that $53 \%$ of university academic staff hold master's degrees, while $35 \%$ have first degree qualifications. The percentage of Ph.D. holders is $11 \%$. Though the percentage of doctoral degree holders still is low, Ayalew (2017) states the proportion of PhDs has increased 
by $342 \%$ (from 356 to 1,577 in absolute numbers) between 2003 and 2012. Within four years from 2012, the number of Ph.D. holders, including those with specializations and subspecializations, has doubled to 3397 (MOE, 2017).

\section{Figure 3. Qualifications of academic staff in Ethiopian universities (2015/2016)}

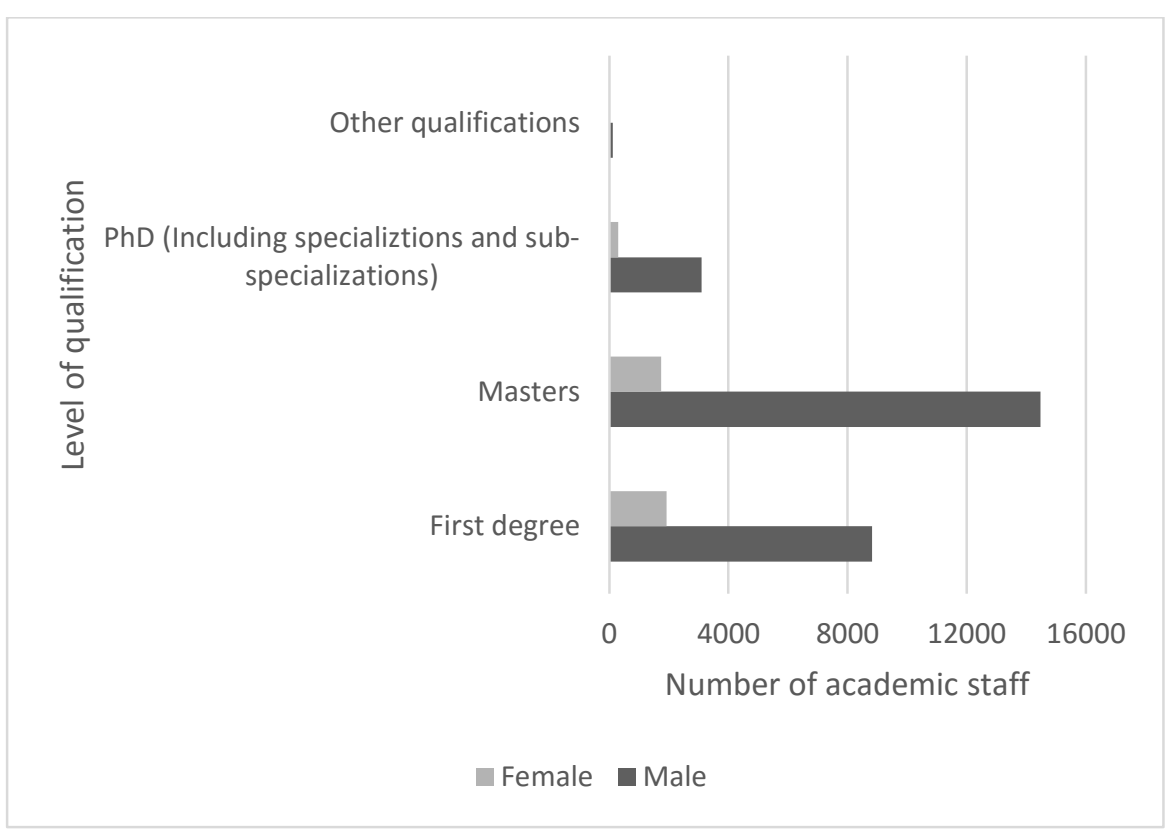

Source: Ethiopian Ministry of Education (MOE) (2017)

The positive development in increasing the number of academics with doctoral-level qualifications does not seem to be sufficient when considering the expanding higher education landscape's needs. For instance, Weldemichael (2014) states that, at Mekelle University in the North, one of the most prominent public universities in the country with relatively high research impact, there were less than three Ph.D. holders for one thousand students. It is also worth pointing out that almost half of the total Ethiopian university staff with doctoral qualifications are Addis Ababa University employees, the flagship university of the country. For instance, for the academic year, 2009-2010, the university had as many as $530 \mathrm{Ph}$. D. holders while the remaining 21 universities had only 586 altogether (Areaya, 2010; Ayalew, 2017). 
As already mentioned briefly above, another major challenge in Ethiopian higher education in terms of staffing is the heavy teaching workload which academic staff are increasingly experiencing because of the expansion of the system which does not go along with academic staff development (Tessema 2009; Weldemichael, 2014; Ayalew 2017). For instance, the teacher-student ratio has risen from 1:8 in 1995 to 1:15 in 2015 to 1: 20 in 2016 (MOE, 2017; Reisberg \& Rumbley, 2015). Reisberg \& Rumbley (2015) state the reasons for this situation: "The (Ethiopian higher education) system struggles to fill many teaching vacancies given the absence of enough qualified Ethiopians to fill these positions. As a result, instructors are also hired from abroad. Most universities do not have the resources to effectively supervise or mentor so many new and inexperienced instructors" (p. 24).

When considering Ethiopian higher education in terms of academic freedom and the intellectual space in higher education institutions, research indicates that there have been concerns both at the institutional as well as researchers' levels via the country's Higher Education Proclamation (2009), which, in Article 16, states that "academic freedom shall be guaranteed for every institution in pursuit of its mission and consistent with international good practice". Academic freedom seemed to be higher during the imperial regime 50 years ago than it is today (Assefa, 2008; Asgedom, 2007). The curtailing of academic freedom, which started towards the downfall of the imperial regime in the 1960s and 70s, and which went to the extent of placing universities under 'complete silence and mere ideological compliance' during the era of the military Derg regime, seems to have continued to this day (Asgedom, 2007). In the past three decades, limitations to academic freedom have been manifested through politically motivated detentions of university professors, undemocratic institutional culture, alienation of staff and students, limited institutional and academic power in terms of student admission, placement and evaluation, limited institutional and professors' rights in deciding and revising 
curriculum content, top-down decision making and limited participation in the process, absence of institutional charter, campus raids by police, and resignations of influential university professors (Assefa, 2007; Asgedom, 2007; Ayalew, 2017; Altbach, 2001). Other issues that might have compromised academic freedom for university staff, according to Assefa (2008), are limited right to establish professional associations and "the student (enrolment) explosion."

Another issue related to academic staff in Ethiopian higher education is the so-called 'brain drain' (Van Deuren, 2015; Teferra \& Altbach 2004; Wondimu, 2003; Ayalew, 2017). Academics from universities in the country tend to migrate to other sectors, countries, and continents in large numbers, searching for better opportunities and working conditions. Though the number varies from institution to institution, the estimate of the brain drain from Ethiopian universities might be as much as 50\% (Teferra \& Altbach 2004). Within the country, internal mobility and brain drain manifests itself with the movement of academic staff from new universities to well-established and less remote ones, and from public universities to private ones, whose salaries are as much as three times higher than public universities' pay scales (Van Deuren, 2015; Teferra \& Altbach, 2004). Gurmessa \& Bayissa, (2015, p. 328) also state that the low pay and non-performance based remuneration has led to a "high exodus" of top talent to other industries. In a study on remuneration in Ethiopian public higher education, Ayalew (2012) concurs with Altbach et al. (2012) in that compensation is at the heart of the brain drain crisis in the country. Ethiopian academics also move to other African countries in search of greener pastures. For instance, according to Teferra \& Altbach (2004), several senior scholars from Addis Ababa University hold faculty positions at the University of Botswana. The South to North movement of academics is also negatively affecting higher education in Ethiopia, like in the rest of Africa. By some estimates, there are more Ethiopian doctoral degree holders abroad than there are in the country (Altbach, 2007). Ethiopians who travel abroad for further education and training tend not to return to the country (Wondimu, 2003). 
Consequently, comprising academic freedom, salary and remuneration, limited professional advancement and research, excessive red tape on human resource and financial management procedures, and a less conducive work environment also seem to point towards a low level of motivation and engagement of academic staff in Ethiopian universities (Gurmessa \& Bayissa, 2015; Ayalew, 2017; Yigezu, 2013). The substantial gender imbalance, as demonstrated in Figures 2 and 3, is also one massive challenge for Ethiopian higher education. Currently, only $11.72 \%$ of the total academic staff in Ethiopian universities are female, which is a mere half of the overall low 22.2\% average for Sub-Saharan Africa (World Bank, 2015).

\section{FUNDING AND RESOURCES}

The Ethiopian government spends more than $1.5 \%$ of the national gross domestic product on higher education which is one of the highest in Sub-Saharan Africa (UIS, 2010), and which, in addition, makes Ethiopia one of the top spenders on the higher education worldwide (Molla \& Cuthbert, 2016). According to data released by The World Bank, expenditure on tertiary education in Ethiopia accounted for $42.7 \%$ of the country's total education budget in 2015 (UNESCO, 2017). Even though The Higher Education Proclamation (FDRE, 2009) stipulates that "Public institutions shall be funded by the federal government or states through block grant system based on strategic plan agreements" (Article 62), the Ethiopian higher education system currently follows the line-item budgeting model (Asgedom \& Hagos, 2016). The government, as of the 2012/2013 fiscal year, allocates budget to public universities in four categories, namely: learning and teaching, research and development, consultancy and community services, and management and administration (Mamo, 2015). Ethiopian public universities negotiate their budget with the government on an annual basis.

Though heavily dependent on state funding, Ethiopian public higher education institutions are by law allowed to be engaged in income-generating activities (FDRE, 2009, 
Articles 66 \& 67). Universities, however, do not seem to be proactive in diversifying their funding base by strengthening their internal revenue mechanisms and, in parallel, seeking external funding other than the state (Waweru \& Abate, 2013). According to Mamo (2015), Ethiopian universities generate only approximately 5\%-10\% of their total recurrent budget from their income-generating activities, which include:

- collecting tuition fees from students who are not covered under the cost-sharing initiative,

- seeking donor funding,

- seeking financial assistance and partnerships with regional and local institutions,

- providing campus services,

- engaging in selling agricultural products and providing consultancy services (Mamo, 2015; Waweru \& Abate, 2013).

Revenue generated in terms of tuition fees from so-called 'non-regular' students (both undergraduate and graduate) like those enrolled in evening, weekend and summer programs accounts for the most substantial amount of internally-generated income for Ethiopian public universities (Mamo, 2015; Yigezu, 2013).

With regards to tuition fees collected from regular students, the country has adopted a cost-sharing scheme which stipulates that beneficiaries pay "a graduate tax" amounting to $15 \%$ of tuition-related costs to the government after completing their studies by paying at least $10 \%$ of their monthly income (FDRE, 2003a, 2009). The Higher Education Proclamation states that the decision about the amount a beneficiary owes the state falls within the Ethiopian Ministry of Education jurisdiction: "The cost of education and training shall be revised at least every three years. The Ministry shall enact directives to this effect." (FDRE, 2003b, Article 4). 
However, there are some challenges with the current funding model and practices that have ramifications for the quality of education and knowledge production. Firstly, there is heavy dependence of Ethiopian public universities on state funding, which, at 60-70\%, is spent on salaries and providing food and accommodation to students, rather than academic activities like research and innovation, publications, and postgraduate studies (Yigezu, 2013). This pattern of funding allocation coupled with the limited capacity of universities to generate internal revenue and seeking external funding has implications for higher education research and graduate studies in particular since much of this funding does not come from direct government funding but from international partnerships and donor funds instead (Gebremariam, 2010; Ayalew, 2017). For instance, in Addis Ababa University, where a considerable amount of the country's postgraduate education and research takes place, Yigezu (2013, p. 59) assesses that the amount of budget allocated for masters and Ph.D. students as well as faculty is "by far inadequate." Even the limited income-generating activities Ethiopian universities are engaged in are heavily skewed towards teaching and learning while generating limited income related to research and development (Waweru \& Ababte, 2013).

A lack of flexibility regarding procurement procedures and inefficiency in using existing resources is also considered obstacles to overcome to improve resource utilization and funding. As Waweru \& Abate (2013, p. 95) found out, in Ethiopian public universities. "facilities are underutilised and procurement systems largely inefficient. More could be accomplished with existing facilities if universities were flexible with time usage and efficient procurement systems." This budgetary red tape and inflexibility also affect research in Ethiopian public higher education institutions, with researchers describing financial procedures as a "nightmare" (Yigezu, 2013). The "rigid and stringent" procurement procedures also seem to have led to under-spending (Yigezu, 2013; Ayalew, 2017). For example, in 2010-2011, 
Addis Ababa University, with its faculty of almost 2,200 and 19,000 students in graduate programs was allocated a budget equivalent to US\$150,000 for research and development, $17.6 \%$ of which had not been spent by the end of the financial year (Ayalew, 2017).

Another funding-related concern is the limited financial autonomy of the country's universities (Mamo, 2015; Yigezu, 2013; Waweru \& Abate, 2013). In terms of financial management, Mamo (2015) states that "The universities are not legally allowed to move funds between budget heads without passing stringent approval procedures. Nor are they able to borrow money to expand their revenue generation" (p. 158). Universities are not allowed to keep surplus from their annual budget granted by the state either (Mamo, 2015); they have to return the unused financial resources at the end of a given budget year to the government treasury. Though Ethiopian universities seem to enjoy more autonomy in owning buildings and other related infrastructure, they cannot rent, lease, or sell them (Mamo, 2015).

The limits on institutional financial autonomy also extend to decisions related to the costsharing system. It seems that Ethiopian higher education institutions have the power and duty only to implement policy. The proclamation on the cost-sharing scheme does not state if higher education institutions are to be consulted while making decisions related to study fees. Article 12 of the proclamation illustrates this concern:

Without prejudice to other provisions in this Regulation, institutions shall have the following powers and duties: (a) to follow up the implementation of the cost-sharing system; (b) to notify the beneficiary, at the beginning of the academic year, the appropriate amount of cost the beneficiary has to share, and to keep record of all necessary data; (c) to provide the beneficiary with documents stating the amounts that are to be paid by beneficiaries.

Besides the limited involvement of universities in the policy-making and setting fees, the costsharing scheme is critiqued in terms of its efficiency to generate revenue for the state in the 
short term. Weak tax collection capacity and a lack of information on graduate mobility are also some of the systemic challenges to be addressed if the scheme is to be implemented successfully (Ayalew, 2013; Van Deuren et al., 2016).

The Ethiopian higher education system also seems to be affected by decreased perstudent budgetary allocations (Saint, 2004; Semela \& Ayalew, 2008; Ashcroft, 2010; Reisberg \& Rumbley, 2010; Semela, 2011). According to Van Deuren et al. (2016), annual allowances per student seem to have decreased from over $\$ 2,000$ to approximately $\$ 850$ when student welfare subsidies are included and approximately $\$ 636$ when those subsidies are excluded. This situation leads to reduced overall budget availability.

The following recommendations were made to improve issues related to funding in Ethiopian higher education:

- For sustainable financing of higher education, encouraging university-industry partnerships (Yigezu, 2013; Waweru \& Abate, 2013). According to Waweu \& Abate (2013), none of the universities they surveyed has established productive universityindustry linkages.

- Encouraging public-private partnerships, Yigezu (2013) recommends that services like housing and catering can be provided by the private sector, hence relieving the government from bearing the brunt of financing such services and enabling it to direct more funding to academic activities like research and development. Waweru \& Abate (2013) also recommend the contracting and outsourcing of non-core activities to reduce costs. They state that outsourcing also benefits universities by "lessening the supervision burden for university staff, reducing the non-academic workforce...improving performance levels and introducing greater flexibility in the application of university funds" (Waweru \& Abate, 2013, p. 95). 
- To enhance and strengthen universities' internal revenue generation capacity, higher education institutions need to be given targets and need to come up with strategies. Besides, institutional entrepreneurial activities need to be encouraged (Yigezu, 2013; Waweru \& Abate (2013). To strengthen and sustain revenue generated from selffinancing students, Waweru \& Abate (2013) suggest the "need to institute demanddriven academic reforms. Consultancy services, if instituted properly, could also generate more revenue in Ethiopian public universities" (Waweru \& Abate, 2013).

- To provide more access at a reduced cost, taking advantage of distance education is suggested. The initiative to establish the Ethiopian Virtual Campus to connect 14 public universities with e-learning platforms and the idea of creating an Ethiopian Open University need to be revisited, according to Yigezu, (2013).

- Other recommendations include extending the cost-sharing initiative to cover graduate studies and students in private higher educations (Yigezu, 2013) and increasing the flexibility of funding management while strengthening institutional financial autonomy through decentralized and participatory management (Yigezu, 2013; Waweru \& Abate, 2013).

\section{RESEARCH OUTPUT}

To date, there appears to be no systematic way of measuring research output in Ethiopian universities based on indicators like publications and conferences organized on both the national level and institutional levels. Nevertheless, the most recent Web of Science report from 2017, which assesses current trends in East African higher education research between 2007-2016 - by analyzing more than 18,000 scientific and scholarly journals, proceedings and book chapters from all research areas - states that research outputs in health and environmental 
and agricultural sciences are the top disciplines Ethiopian researchers engage in during the past ten years.

Figure 4. Top 6 subject areas of Ethiopian research, measured by the number of research papers published in the most influential scientific journals

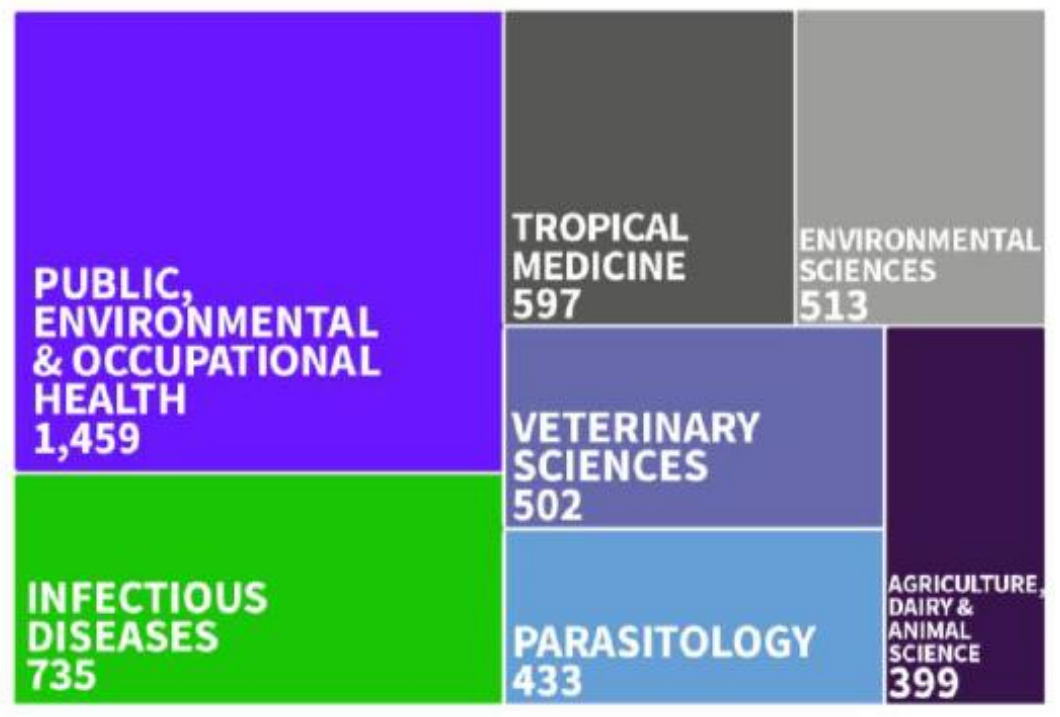

\section{Source: Web of Science Analytics InCites (2017)}

The above finding that research is focused on medical and health sciences is also backed up by a World Bank report by Blom et al. (2015), which indicates that $21 \%$ of the research produced in Ethiopia is concentrated on this particular field. From the report, it can be inferred that close to $70 \%$ of research in the country is concentrated on medical sciences, engineering, agriculture, and the natural sciences. The share of engineering is only $6 \%$. Like in the other parts of Africa, research in STEM fields seems to be lagging behind other disciplines (Blom et al., 2015), though policy-wise the country gives considerable attention to the central role science and technology play in terms of achieving the goals set by the Agriculture Development Led Industrialisation (ADLI) national development strategy.

At the institutional level, the national flagship higher education institution, Addis Ababa University, is leading in research productivity. For instance, the number of publications originating from the university has increased by $63 \%$ from 246 publications in 2011 to 417 in 
2014 (Teshome, 2016). The university claims that its research output places the institution ahead of the University of Nairobi and Dar Es Salaam, but behind Makerere, Cairo, and Cape Town (Teshome, 2016). According to the aforementioned Web of Science Analytics (2017) statistics, the Universities of Gondar, Jimma, Mekelle, and Hawassa take second, third, fourth, and fifth place after Addis Ababa University as the most research-productive universities in the country. As for producing impactful research, however, Mekelle University seems to be ahead of the other four, with the average research paper published from the university in the last ten years was being cited 2.6 times more than the world average (Web of Science, 2017) as shown in table 1 below.

Table 1. Normalized citation impact of Ethiopian Universities

\begin{tabular}{lll}
\hline Name of institution & research output & Normalized citation impact \\
\hline Addis Ababa University & 3449 & 1.23 \\
University of Gondar & 994 & 1.58 \\
Jimma University & 833 & 0.98 \\
Mekelle University & 733 & 2.60 \\
Hawassa University & 676 & 0.71 \\
Total & 6685 &
\end{tabular}

\section{Source: Web of Science (2017)}

Despite these figures, and although the research function is given priority in policy documents like ESDP V (MOE, 2015) and university mission and vision statements, research output from the country's higher education system is still considered low. Ethiopian higher education remains overwhelmingly teaching-oriented (Van Deuren et al., 2016; Cloete \& Maassen, 2015), and the impressive gains made in expanding the country's higher education system do not seem to be accompanied by a parallel expansion in terms of research productivity 
(Van Deuren et al., 2016; Weldemichael, 2014; Ashcroft \& Rayner, 2011). For example, at Mekelle University, the institution with considerable research impact, among 1456 academic staff members, not more than 25 articles were published in 2013 (Woldemichael, 2014). A case study at Jimma University confirms that university teaching staff are only marginally engaged in research (Melese, 2012). This low engagement with research also extends to the acquisition of patents: in 2010, the country had no patent applications, whereas South Africa had 821 applications. This situation is indicative of the challenges related to converting knowledge into innovation and technology transfer in Ethiopia (Molla \&Cuthbert, 2016). As a core function of higher education, research does not seem to be given due attention, let alone financial and human resources. Academic staff members in many universities - though officially, university academic staff are expected to dedicate $25 \%$ of their time doing research while teaching is expected to take up $75 \%$ of their workload (FDRE, 2003; Woldemichael, 2014).

In addition to a poor research culture (Jowi \& Obamba, 2011), low research productivity in Ethiopian higher education is also linked to the low or "chronic underinvestment" and financial support which is given to this function of higher education (Kitaw, 2006). The latest Education Sector Development Program (ESDP V) indicates that research funding in Ethiopian universities accounted for only $1 \%$ of their total budget (MOE, 2015). Compared to other countries in Africa, for example, South Africa, Ethiopia's research and development expenditure was three times less(UNESCO, 2010; Molla \& Cuthbert, 2016). Many public universities, including the national flagship university, Addis Ababa, also seem to depend on limited government and donor funding for research and lag behind African counties in terms of seeking grants and international research funding (Teshome, 2016). Yigezu (2013) also expressed the concern that higher education institutions like Addis Ababa University have budget expenditures which are "skewed towards salaries and food than academic activities" leaving only about "30-40\% of the recurrent budget for the critical 
elements of academic activities such as research, publication, innovation and postgraduate training.

In addition to challenges pertaining to funding, other reasons provided for the limited research engagement and productivity include: qualitative and quantitative shortages of research staff, limited research infrastructure, lack of clear research priorities and agendas, and inadequate research management and support systems (Kitaw, 2006; MOE, 2015; Weldemichael, 2014; Ishengoma, 2016). Constraints on academic freedom also limit academic staff's aspirations in taking the initiative to conduct research and address critical societal issues (Weldemichael, 2014). Low graduate student enrolment, too, results in limited research outputs since a considerable amount of higher education research is derived from research undertaken by graduate and postgraduate students (MOE, 2015).

In order to improve the quality, quantity, and relevance of research in the country and address the issues mentioned above, a national research undertaking framework is proposed to be developed after higher education institutions will have identified and submitted their research areas considering their staff profiles, areas of research strength, and local needs. A national forum co-chaired by the MOE and the Ministry of Science and Technology has already been set up to enable enhanced collaborations between higher education institutions and industry (MOE, 2015). Business incubation centers at the institutes of technology and science and technology universities are also expected to improve income-generation in universities (MOE, 2015). Performance-based research funding and reward systems are also included in the Education Sector Development Program to encourage research excellence, relevance, and alignment with national development objectives. Encouraging inter-institutional quality assurance and collaboration between universities and international institutions are also part of the plan to enhance research capacity (MOE, 2015). 
However, there are other challenges that these policy decisions do not seem to cover. Driven by the need to harness the powers of research for national development, much of the limited research in Ethiopian universities currently focuses on applied research (FDRE, 2010b, 2012; Molla \& Cuthbert, 2016). This scenario might be discouraging for institutions and researchers who aspire to conduct basic research. Bridging the wide research capacity deficit between new and first-generation universities (Molla \& Cuthbert 2016) is topical in the country's higher education system since newly established universities lag in terms of their postgraduate programs, which, in turn, negatively affects their research capacity. By 2013, out of 31 public universities in the country, only eight of the relatively well-established ones provided doctoral education, with again more than half of all doctoral students being enrolled in Addis Ababa University.

Furthermore, the status of research specifically focusing on issues pertaining to higher education studies, is a cause of concern, especially considering the need for evidence-based decisions in a system that is undergoing rapid expansion and reform. Out of 1,250 published and unpublished research articles between $1974-1999$, only 57 documents deal with issues related to higher education (Asgedom, 2007). A recent upsurge in higher education studies research, however, is an encouraging development.

As indicated at the beginning of this section, this overview of research output and productivity in Ethiopian higher education indicates the need to systematically develop instruments, frameworks, databases, and research repositories to measure and archive research and publications at the national or institutional level. Much of what has been written about research intensity in the Ethiopian context does not back up claims with quantitative evidence. In terms of archiving research and making it available via open access, initiatives like the Ethiopian Journals Online (EJOL) launched in 2014, and currently hosts 18 journals, need to be encouraged and expanded. 


\section{INTERNATIONALISATION}

Internationalization is one of the major forces shaping higher education in Africa in the 21st century (Jowi, 2009). African universities have begun to acknowledge that internationalization initiatives can no longer be sidelined, but should increasingly be a central part of university activities (Jowi et al., 2013). Like elsewhere on the continent, Ethiopian universities attach a high importance to this phenomenon (Tamrat, 2015; Tamrat \& Teferra, 2018). The significant manifestations of internationalization in the country's higher education system, according to Oyewole (2009) include:

- trans-national providers licensing

- private providers with external support

- partnerships

- employment of professors from fellow African countries but with emoluments higher than the local academics

- collaborative research and institutional linkages, with the establishment of

- international research centers

- joint programs

- distance education

- invitations to foreign academics

- $\quad$ student mobility( p. 325)

Though Semela \& Ayalew (2008) stated that the primary motivation to internationalize Ethiopian higher education has been the desire to develop globally competitive higher education institutions that meet international quality standards, Tamrat (2015) argues that internationalization initiatives are driven by internal capacity development needs of the 
expanding higher education sector in the country. The highest level of importance is accorded to engaging in international development projects, strengthening international research collaborations, establishing joint academic programs with international partners, and improving the overall quality and standard of education among the activities outlined above (Tamrat, 2015). The motivations for internationalization that dominate higher education systems in other parts of the world, such as attracting international students and other regional and continental integration issues, do not attract much attention among the country's universities (Tamrat \& Teferra, 2018; Tamrat, 2015).

According to a survey of nine public and six private higher education institutions in the country, strengthening teaching and learning, promoting student and teacher development, and enhancing standards and quality were found to be the major perceived advantages gained from internationalization initiatives, in contrast to other perceived benefits like promoting multiculturalism and cultural awareness and enhancing competitiveness, which are frequently stated in the internationalization literature as advantages (Tamrat, 2015). The same survey indicates that the main perceived risks associated with internationalization, according to the respondents, are brain drain, increased costs, and loss of cultural identity.

As far as international collaborative capacity development projects are concerned, Europe is found to be the preferred continent for Ethiopian universities, followed by North America (Tamrat \& Teferra, 2018). When it comes to specific countries, Sweden (through SIDA and its research cooperation department, SAREC), the US and Germany take the first three places (Tamrat, 2015). Several Norwegian universities have also been working in partnerships with Ethiopian higher education institutions in agriculture and natural resources management for more than a quarter of a century (Ishengoma, 2016). The Dutch International Agency for Higher Education (EP-NUFFIC) and the Belgian International Agency for Higher Education (VLIR-OUS), and the Finnish National Agency for Education also fund 
transcontinental higher education projects between Ethiopian universities and the ones that are in their respective countries. International agencies like UNESCO and the World Bank also engage in higher education capacity building projects.

Some questions have, however, been raised as to the impact and effectiveness of such collaborations. Lack of institutional directions and strategies is one of the challenges. Many of these collaborations seem to be the products of individual initiatives that are not managed, organized, and communicated systematically at the institutional level (Ayalew, 2017; Tamrat $\&$ Teferra, 2018). The fact that the capacity development collaborations are mainly NorthSouth also seems problematic. Power asymmetries, mismatched and incompatible goals between Southern and Northern partners, and well as a lack of long-term perspectives and sustainability issues are also mentioned as possible reasons why such research and capacity building initiatives might not be as effective as intended (Osama, 2008; Ishengoma, 2016). Tamrat \& Teferra (2018) explain what they termed as 'lopsided partnerships' between Ethiopian universities and their Northern partners: "In most cases, local institutions are mere 'recipients,' and the elements of reciprocity are not evident. There have also been instances of Northern partners seeking to achieve their own objectives without too much regard to the needs and aspirations of their local partners and, at times, their own funders”. (p. 19)

Lack of strategizing and in this way 'donor-recipient framework' manifested research collaborations between Ethiopian and Northern partners might also lead to the tendency to reproduce "traditional patterns of economic and geographical dependency" (Jowi 2012, p. 51) rendering Ethiopian institutions and researchers relatively powerless (Ali et al. 2006). In addition to strategizing and institutionalizing such internationalization initiatives, assessing the impact of such projects at different levels through effective monitoring and evaluation mechanisms is, therefore, an activity area that deserves more attention. 
Apart from international capacity development projects, trans-national collaborative research seems to be one significant aspect of internationalization of higher education in Ethiopia, as it is the case elsewhere. A Web of Science (2017) report that assesses recent trends in higher education research in East African countries between 2007-2016 concludes that the most effective way for Ethiopian higher education institutions and researchers to get more research visibility is actually to collaborate with their international and regional partners through exchanging knowledge and experience.

\section{Figure 5. Ethiopian researchers' international research collaborators}

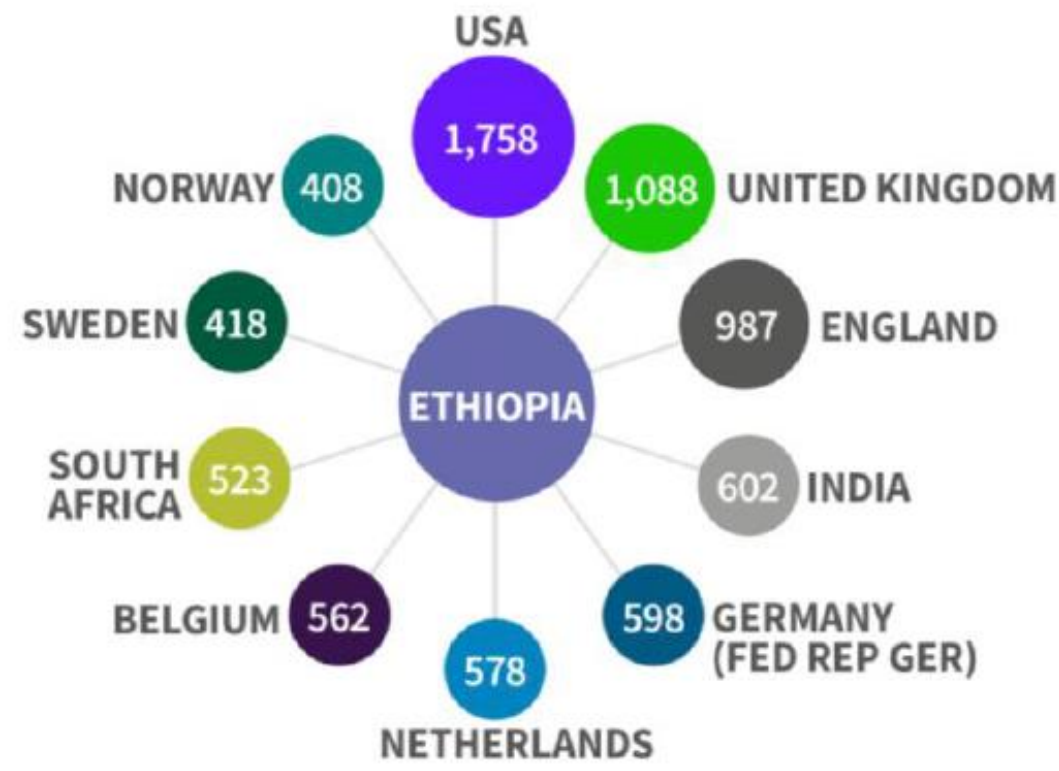

\section{Source: Web of Science (2017)}

According to the report, out of more than 7526 research papers published by Ethiopian researchers between 2007 and 2016, more than 1700 were co-authored with colleagues from the United States, followed by those from the United Kingdom. Ethiopia seems to have the same 'leading' partners as the rest of East African nations. It becomes apparent, however, that the country does not seem to be exploring Intra-East African research collaborations, which countries like Kenya, Uganda, and Tanzania are taking advantage of. For instance, it is 
interesting to note that, for Kenya, Uganda and Tanzania appear on the top ten of its collaborators, and a similar trend is observed for Uganda in that Kenya and Tanzania take two of the spots in the list of its top ten collaborating countries.

Looking at internationalization from the vantage point of international mobility of Ethiopian students, it can be observed that initiatives mainly focus on educating master and Ph.D. students in engineering and health sciences, i.e., disciplines in which the country's higher education system has a considerable shortage of trained personnel (Tamrat \& Teferra, 2018; Tamrat, 2015; MOE, 2008). The United States, India, Italy, Saudi Arabia, and Finland are the top five countries where Ethiopian students study abroad (UNESCO, 2017), as can be seen from Table 2 below.

Table 2. Destinations for Ethiopian international students

\begin{tabular}{ll}
\hline Destination country & Student number \\
\hline United States & 1539 \\
India & 549 \\
Italy & 398 \\
Saudi Arabia & 355 \\
Finland & 352 \\
Turkey & 328 \\
Germany & 262 \\
Norway & 257 \\
South Africa & 229 \\
Korea Rep & 208 \\
\hline
\end{tabular}

Source: UNESCO Institute of Statistics (2017) 
Though Ayalew (2017) states that inbound student mobility has a long history in Ethiopia, dating back to the 1950s, when international students from counties like Tanganyika, Kenya, Greece, India, the UK, the former Yugoslavia, and the USA, accounted for $13 \%$ of the student population at Addis Ababa University, there seems to be almost no up-to-date and systematically compiled data on international student mobility to Ethiopia today as Semela and Ayalew (2008) observed ten years ago. Regarding the international staff at Ethiopian universities, in 2016, out of a total of 30,496 academic staff, 1499 were expatriate ones, with the vast majority, 1,437, in public universities and as little as 62 in private ones (MOE, 2017). The presence of international staff seems to be driven by what Tamrat and Teffera (2018) refer to as "emerging needs" of the higher education system, which is to address shortages of personnel for the expanding higher education system (Akalu, 2014; Reisberg \& Rumbley, 2015). The development of their presence over five years can be seen in figure 6 below.

Figure 6. International staff in Ethiopian universities (2011-2016)

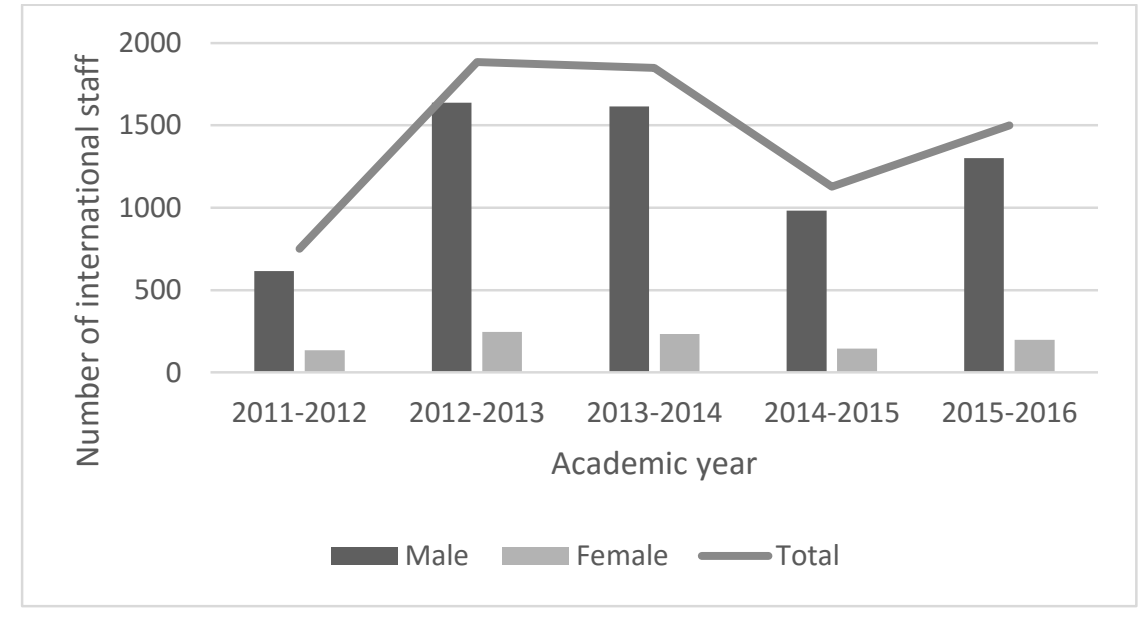

\section{Source: Ethiopian Ministry of Education (MOE) (2017)}

Compared to the academic year 2011-2012, the total number of expatriate staff doubled in 2011-2016. International staff comes from India, the Philippines, Nigeria, Cuba, the UK, Germany, Ireland, and the USA (Saint, 2004; Molla, 2015). Nevertheless, in contrast to the 
international capacity development projects and research collaborations, academics from the global South constitute the majority in staff mobility.

\section{CONTINUING EDUCATION FOR WORKFORCE DEVELOPMENT}

The limited amount of past and present policy-making and existing literature on continuing adult education and lifelong learning in Ethiopia focus on basic adult literacy and vocational education (MOE, 2008, 2010; Abiy et al., 2014; Molla, 2010). When considering the matter from the vantage point of higher education, this particular dimension of education seems to be a recent phenomenon relatively unrecognized in higher education policy and reform (Semela \& Amadi, 2010).

The first diploma-granting program in continuing education was launched in 1980 in Bahirdar University, and until the coming to power of the EPRDF-led government in 1991, the role post-secondary institutions played in promoting adult education was at best marginal (Semela \& Amadi, 2010). Currently, Ethiopian universities have Kiremt (summer), evening, and distance-education programs providing education for non-regular and non-traditional students. According to the latest statistics by MoE, $45.43 \%$ of students -a total of 353,820 enrolments out of 778,776 total national enrolments - enrolled in undergraduate programs belong to this category. Out of these, $38.9 \%$ are enrolled in evening programs, while 34.97 $\%$ and $26.13 \%$ are enrolled in summer and distance programs, respectively (MOE, 2017). Like in regular programs, there is a noticeable gender imbalance in continuing education programs with $32.53 \%$ female and $67.47 \%$ male.

Consequently, considering that continuing education accounts for nearly half of the total undergraduate student enrollment in the country's universities and that continuing education programs serve as relevant sources of revenue for Ethiopian universities, it can be argued that existing literature well as dedicated policy-making, is too limited. Even though the Education and Training Policy of 1994 acknowledges adult education provision, there is no further 
reference to continuing education and training at the post-secondary level. The role postsecondary institutions could potentially play as avenues of lifelong learning is not discussed in the document, either. This same observation also applies to the 2008 National Adult Education Strategy (NAES) and the country's Higher Education Proclamations. The fifth Education Sector Development Plan (MOE, 2015) has, however, introduced post-literary strategies as one of the priority areas of adult and non-formal learning. The document states that the goal of this priority area is: "to create a learning society by providing adult and non-formal education linked to lifelong learning opportunities that meet the diverse learning needs of all and which contributes to personal, societal and economic development" (MOE, 2015, p. 87). However, these policy documents do not include any organizational, curricular, and admission-related issues on continuing education, especially at the university level (Semela \& Amadi, 2010). The curriculum of continuing education programs in Ethiopian universities is the same as providing regular or so-called 'traditional' students in terms of content, teaching, and assessment methods. Admission requirements are equally inflexible for these programs in that only those who complete pre-university education are eligible to join continuing education programs. This implies sitting for a higher education entrance examination and hence excluded able adults with practical skills and scientific or indigenous knowledge (Semela \& Amin, 2010).

Ethiopian universities do not presently feature a system to recognize prior learning, i.e., knowledge and skills acquired at the workplace or home, and "downward linkages," allowing learners to establish equivalence for credentials acquired in community colleges as adult education centers are equally not in place (Semela \& Amadi, 2010).

Though O'Keeffe (2016, p.800) states that courses designed to improve existing knowledge of fields like animal husbandry, horticulture and agro-biotechnology, and marketing and management, are central to Ethiopian universities and are therefore manifestations of the " promotion of lifelong learning for all', a lot remains to be done in terms 
of institutionalizing professional development courses which take into account adult learners' needs. Many of the students enrolled in continuing education platforms are registered in degree and diploma awarding programs taking years to complete. The argument by Semela \& Amin (2010) regarding the absence of an institutionalized structure for organizing short professional development programs in Ethiopian universities is still relevant today. National and institutional continuing and professional development tailor-made courses could be incorporated into continuing education curricula.

In the present public universities' organizational structure, units labeled 'continuing education coordination offices' or 'continuing and distance education coordinating offices' are charged with managing issues related to this aspect of higher education (Mekonnen 2005; Semela \& Amadi, 2010). Nevertheless, these offices are frequently under-resourced. They have only a limited degree of autonomy and are often seen as 'appendages' to regular programs despite their considerable student intake.

\section{GRADUATE EDUCATION AND CAPACITY DEVELOPMENT}

As a pioneer, Addis Ababa University began offering graduate programs in October 1978 (AAU, 1980; Ayalew, 2017; Bishaw \& Melesse, 2017). Since then, graduate studies have been diversified and expanded through other public universities, namely Hawassa, Harramaya, Gondar, and Jimma (Ayalew, 2017). To illustrate the recent expansion of graduate studies,Molla and Cuthbert (2016) state that, in 1999, there were only 22 Ph.D. students in Ethiopia; that number, however, grew by a factor of 35 to 789 in 2011 (Ayalew, 2017). Between 2011 and 2016, masters and Ph. D. enrolments in the country have increased by more than 30,000 enrolments (MOE, 2017). MoE statistics also indicate that, compared to 2015, in 2016 alone, total graduate enrolments have increased by more than 10,000. As observed in Table 3 below, total graduate enrollment in Ethiopian universities has more than doubled in the past six years. 
Since 2014, the total graduate enrollment has shown a 20 fold increase (MOE, 2017). However, it is worth pointing out that this graduate enrollment expansion is mainly focused on public universities, as is the increase in undergraduate enrolments: in $2016,84.6 \%$ of students registered on graduate programs pursued their studies at government institutions (MOE, 2017).

Table 3. Graduate student enrolment in Ethiopian universities (2010-2016)

\begin{tabular}{|c|c|c|c|c|c|c|c|}
\hline & & $2010 / 2011$ & $2011 / 2012$ & $2012 / 2013$ & $2013 / 2014$ & $2014 / 2015$ & $2015 / 2016$ \\
\hline \multirow{4}{*}{$\begin{array}{l}\text { Masters } \\
\text { (Public) }\end{array}$} & Male & 15996 & 18169 & 20060 & 20871 & 23129 & 34398 \\
\hline & & & & & & & \\
\hline & Female & 2490 & 4635 & 5043 & 5246 & 7337 & 9706 \\
\hline & Total & 18486 & 22804 & 25103 & 26117 & 30466 & 44104 \\
\hline \multirow{4}{*}{$\begin{array}{l}\text { Masters } \\
\text { (Private) }\end{array}$} & Male & 682 & 779 & 2339 & 2433 & 4820 & 2779 \\
\hline & & & & & & & \\
\hline & Female & 193 & 228 & 679 & 725 & 1866 & 1913 \\
\hline & Total & 875 & 1007 & 3018 & 3158 & 6686 & 4692 \\
\hline \multirow[t]{5}{*}{ Ph.D. } & Male & 690 & 1530 & 2809 & 2922 & 2755 & 2444 \\
\hline & Female & 99 & 319 & 356 & 370 & 380 & 281 \\
\hline & Total & 789 & 1849 & 3165 & 3292 & 3135 & 2725 \\
\hline & Grand & 20150 & 25660 & 31286 & 32567 & 40287 & 51521 \\
\hline & Total & & & & & & \\
\hline
\end{tabular}

\section{Source: Ethiopian Ministry of Education (2017)}

Some Ph.D. students attend their studies in sandwich or distance programs. According to Hayward \& Ncayiyana (2014), for example, efforts to increase the number of Ph.D. faculty members in Ethiopia, underway for a number of years, have established several notable cooperation projects with foreign universities. The most extensive collaboration project, which 
has now been running for a quarter-century, was funded by the Swedish International Development Cooperation Agency (SIDA). It started in 1979 to enhance research, provide capacity building for Ethiopian institutions, and support master's science (Hayward \& Ncayiyana, 2014). Distance graduate programs are provided by universities from India, South Africa, and the UK, among other European countries, with .the largest providers being the University of South Africa (UNISA) and Indira Gandhi University.

As with undergraduate expansion, the increase in graduate enrolments is not without challenges. Gross enrollment in graduate programs, especially at the $\mathrm{Ph}$. D. level is still very low despite overall increased access. In 2016, out of the total of 830,287 enrollments, graduate enrollments only accounted for $6.2 \%$ of the total student intake. Of these, $5.88 \%$ are at masters' level while the Ph.D. level amounts to only $0.33 \%$ (MOE, 2017). In the same year, only $2.5 \%$ of total graduates from graduate studies were from Ph.D. programs (MOE, 2017), making Ethiopia a country with one of the lowest Ph.D. enrollment ratios in sub-Saharan Africa. Though not an up-to-date comparison, Molla and Cuthbert (2016, p. 644) state that, by 2011, "there were only nine Ph.D. students per one million Ethiopians while there were 450, 244, 29 and 17 Ph.D. students per one million of the population in Egypt, Mozambique, Ghana and Niger respectively". The low Ph.D. enrolment is all the more concerning since many of the Ethiopian public universities are aspiring to become research-intensive, and as postgraduate students, especially $\mathrm{Ph} . \mathrm{D}$. students, play an essential role in enhancing research productivity (Cloete et al., 2015, 2017; Taylor, 2006). This concern is also raised by the Ethiopian Ministry of Education in ESDP V (MOE, 2015).

When looking into graduate education and research, considering the country's Agriculture-Led Industrialization (ADIL) national development strategy and the intention of the nation to use higher education for economic development - and more specifically the national policy aspiration of having $70 \%$ of students enrolled in fields related to STEM, - it 
can be observed that more needs to be done in terms of recruiting graduate students into fields like agriculture and life sciences, engineering and technology, computational sciences, and natural sciences. Statistics for 2016 indicate that in public higher education institutions, the highest number of graduate students, at $29.6 \%$, belong to disciplines related to social sciences and humanities with business and economics students take second place with $19.7 \%$ enrollment shares (MOE, 2017). MOE statistics also indicate that Agriculture and Life Sciences have the least percentage of enrolments, with only $8.3 \%$ of students studying in these disciplines. In private graduate education providers, a three-quarter majority, $77.3 \%$, of students are enrolled in business and economics, followed by engineering and technology, taking up $13.7 \%$ of enrollment (MOE, 2017). Like in public higher education institutions, agriculture and life sciences constitute the least enrolment shares with only $0.4 \%$. As of 2017 , there were no graduate students enrolled in natural and computational sciences in private higher education providers (MOE, 2017).

Furthermore, student admission policies, specifically the lack of autonomy in institutional decision-making, influence the quality of graduate education and training. Implemented to address the quantitative as well as qualitative shortage of qualified academic staff in the expanding higher education system, the Ethiopian Ministry of Education has reappropriated institutional affairs in centrally determining who should be admitted to graduate schools in the country (Akalu, 2013, 2014; Van Deuren et al., 2015). The academic community criticized this admission strategy for compromising the rigor of entry requirements, among others. For instance, in Addis Ababa University, where the majority of Ethiopian graduate studies are located, Akalu (2014, p. 409) states this admission policy created "” a tug of war" between university departments and MOE. 
This policy is also criticized for limiting access for qualified self-funded graduate students who are not part of the Ministry selection (Akalu, 2013). The MOE itself saw this criticism as a "targeted attempt to boycott government plans" (Akalu, 2014, p. 409).

Correspondingly perhaps, there is both a lack of student preparedness to undertake graduate research and poor quality supervision in regular and distance graduate studies (Molla \& Cuthbert 2016; Woldeyes, 2016; Kahsay, 2015; Mohamedbhai, 2011; Ayalew, 2017). In Addis Ababa University, university staff has a growing concern about "an influx of largely illprepared candidates to universities' programmes" (Akalu, 2014). Underscoring the need to address this challenge, Akalu further elaborates:

As one associate professor in Addis Ababa University commented on a growing laxity in postgraduate students' efforts in their studies, he had this to say: 'When you start granting admission to a student in the form of charity, why would he/she study in the first place?' (...)). Another professor similarly bemoaned: I have doctoral students who still want me to provide them handouts ... It is unfortunate that we are teachers at this level. We should not be teachers at masters and $\mathrm{PhD}$ levels. Our role must be one of guidance, one of pointing direction. The students should engage in their own readings based on the guidance and direction they receive. (Akalu, 2013, p. 16)

Ayalew (2017) also reported general "apathy and reservations" among Addis Ababa University senior professors regarding supervising and mentoring students partly caused by "the less-motivated and underprepared students." Molla and Cuthbert (2016) also raise challenges concerning inefficiency in Ph.D. studies in the country: the rate of Ph.D. completion is low, and it takes a comparatively long time for students to complete their studies. In 2014, there were around 3,300 doctoral students in the Ethiopian public higher 
education system, but only 80 graduated with a doctorate in the same year (Molla \& Cuthbert, 2016). Completion rates show an increase in 2016, where there were 2725 enrolments and 263 graduations - though the number of graduates in 2016 declined by $14.2 \%$ compared to the previous year (MOE, 2017). Indeed, anecdotal accounts suggest that doctoral completion in Addis Ababa University can also take up to eight years (Molla \& Cuthbert, 2016).

Diversification of graduate programs is yet another challenge in Ethiopian higher education. Doctoral programs by publication, taught doctoral programs, and professional doctorate programs which are part of graduate education and training in countries like South Africa are absent in the Ethiopian higher education system (Molla \& Cuthbert, 2016). At the graduate level, too, gender balance is still far from being achieved with only $23.1 \%$ female graduates as of 2017(MOE, 2017). Likewise, sustainability is raised as a concern regarding financing graduate studies in Ethiopian universities (Ayalew, 2017. A considerable amount of the total budget for establishing and expanding master's and Ph.D. programs is acquired from international aid, donor funding, and universities' internal revenue (Ayalew, 2017; Gebremariam, 2010; Wondimu, 2003). Today, Ethiopian universities seem to depend on international partners like SIDA/SAREC, NUFFIC, and NORAD to finance their graduate research initiatives (Ayalew, 2017). As a result, the inability to fund research and graduate studies could leave developing countries like Ethiopia at the mercy of external funding agencies whose priorities determine the priority areas for research and education (Ali et al., 2006).

In general, national graduate education policy and implementation have focussed on widening access through increasing enrolment. Therefore, more nuanced and realistic policy goals, procedures, and frameworks need to be developed to improve the quality of graduate education and research, diversifying the funding base, and promoting equity (Molla \& Cuthbert, 2016; Woldeyes, 2016). 


\section{CONCLUSION}

This chapter set out to discuss the trends, opportunities, and challenges in Ethiopian higher education in the past decades, focusing on the dynamics of the country's higher education in the past ten years. The Ethiopian system has been characterized by substantial state-led expansion and reforms driven by the motivation to use higher education for national development in the past decade. One of the significant strengths of the country's higher education system has been registered in terms of creating more access. As elaborated in this chapter, enrollment figures for both undergraduate and graduate programs have increased, and attempts have been made to meet the expanding system's staffing needs. The country also dedicates more than $40 \%$ of its education budget to the sector, and there have been encouraging signs in giving more priority to the research agenda of universities - although, like many other universities on the continent - Ethiopian universities are still heavily leaned towards teaching and learning-oriented at their base. Ethiopian universities are shown to be open to working with donors and international partners in capacity-building projects.

Despite the positive developments outlined above, with a gross enrolment rate of merely $8.1 \%$ (UNESCO, 2015), higher education in Ethiopia remains an 'elite' system when framed by the typology developed by Martin Trow (2007), which puts the minimum threshold for a massified system at $15 \%$. Creating more access, therefore, continues to be a considerable challenge. Enrolment figures also indicate that ensuring equitable access is a matter of concern since present-day higher education in Ethiopia is characterized by the under-representation of especially women, geo-politically marginalized ethnic groups, and people from low socioeconomic backgrounds or peripheral regions and rural areas. A focus on 'massifying' the system is often cited as one reason for lowering education quality. 
Correspondingly, research indicates that an increase in the number of academic staff does not catch up with the needs of expanding the system, increasing the teaching load for existing staff members. Besides, there is limited academic freedom, increased brain drain, and excessive barriers to human resource and financial management procedures, among others. When it comes to funding, limited institutional financial autonomy, heavy dependence on state funding, decreasing per-student allocations, and inflexibility of administrative procedures negatively impact the system. Likewise, capacity-building and collaboration projects, which are both significant motivations and manifestations of internationalization of higher education in the country, also need a careful analysis as to how effective they are in terms of impact, sustainability, and relevance. As discussed in this chapter, the potential of higher education as an avenue for continuing education and lifelong learning in Ethiopia needs more exploration, too.

The research function of higher education is equally under-funded as well as underresearched. According to the country's Fifth Education Sector Development Strategy (MOE, 2015 ), only $1 \%$ of universities' total budget is dedicated to research. This is a cause for concern, given that the prevailing global discourse of the knowledge economy is highly dependent on universities' output as knowledge producers and platforms for innovation. If this aspect is not given due attention, Ethiopian universities are expected to lag regarding research and knowledge production in regional comparison and beyond. The limited intake of graduate students, especially Ph.D. students at as little as $2.5 \%$, hampers enhancing universities' research capacity. In addition, low completion rates and lengthy study periods face those few enrolled.

As a concluding remark, I would like to mention that one of the challenges I encountered in writing this paper is the lack of systematically archived data to inform the 
analysis of the various facets of the Ethiopian higher education system. Consequently, I would like to advocate and reiterate the need to monitor benchmark and measure trajectories systematically. Making the data publicly available both at the national and institutional level should be given priority. In particular, this applies to measuring research output and productivity, assessing aspects of internationalization like inbound and outbound student mobility, and accessing information on international research collaborations and capacity development projects. Regarding policy, gaps have been identified in articulating graduate education and research and defining the role universities could play in continuing education and life-long learning. Lastly, it is noteworthy that - though more research is being carried out in various aspects of the system and its institutions- the analysis of national and institutional policy documents and strategies suggests that those outcomes do not seem to have been utilized as inputs to evidence-based higher education policy-making. 


\section{References}

Abebe, G. (1995). Ethiopian traditional education and useful lessons. In IER (Ed.), Proceedings of the national workshop on strengthening educational research (pp. 1 $15)$.

Addis Ababa: Addis Ababa University Printing Press.

Akalu, G. A. (2014). Higher education in Ethiopia: expansion, quality assurance and institutional autonomy. Higher Education Quarterly, 68(4), 394-415.

Akalu, G. A. (2013). “They're for Shopping: Faculty Perceptions of the Quality of Graduate Students in Addis Ababa University". Paper presented at the Research Day of the Department of Educational Policy Studies, University of Alberta. Building bridges, building opportunities, envisioning possibilities. Edmonton: Canada.

Ali, N.; Hill, C.; Kennedy, A. \& Ijsselmuien, C. (2006). What Factors Influence NationalHealth Research Agendas in Low and Middle Income Countries? Paper 5. Geneva: Council on Health Research for Development.

Areaya, S. (2010). Tension between massification and intensification reforms and implications for teaching and learning in Ethiopian public universities. Journal of Higher Education in Africa, 8(2), 93-115.

Asgedom, A. (2005). Higher education in pre-revolution Ethiopia: Relevance and academic freedom. The Ethiopian Journal of Higher Education, 2(2), 1-45.

Asgedom, A., \& Hagos, T. (2016). Governance reforms in higher education in Africa: The case of autonomy and accountability in Ethiopian higher education. In N. V. Varghese (Ed.), Reforms and changes in governance of higher education in Africa (pp. 41-61). Paris: UNESCO.

Ashcroft, K. (2010). Ethiopia: expanding and Improving Higher Education. University World 
News. http://www.universityworldnews.com.

Ashcroft, K. \& Rayner, P. (2012). The Purposes and Practices of Quality Assurance in Ethiopian Higher Education: Journey, Adaptation and Integration. International Journal of Business Anthropology, 3 (2), 19-35.

Assefa, T. (2007). The status of academic freedom in Ethiopia. Peace Review, 19(4), 479-485.

Assefa, T. (2008). Academic freedom in Ethiopia: Perspective of teaching personnel. Addis

Ababa: Forum for Social Studies.

Ayalew, E. (2012). Salary and incentive structure in Ethiopian higher education. In P. G.

Altbach, L. Reisberg, M. Yudkevich, G. Androushchak, \& I. F. Pachecho (Eds.), the professoriate: A global comparison of compensation and contracts (pp. 125-135). New York: Routledge.

Ayalew, E. (2017). Once a Flagship Always a Flagship?Addis Ababa University in Perspective. In Damtew Teferra (Ed.) Flagship Universities in Africa (pp. 91-142). Cham: Palgrave Macmillan.

Bishaw, A., \& Melesse, S. (2017). Historical Analysis of the Challenges and Opportunities of Higher Education in Ethiopia. Higher Education for the Future, 4 (1), 31-43.

Blom, A., Lan, G., \& Adil, M. (2015). Sub-Saharan African science, technology, engineering, and mathematics research: a decade of development. World Bank Publications.

Clarivate Analytics (2017). Scientific Research in East Africa: key trends and observations. Retrieved from:https://clarivate.com/blog/science-research-connect/scientific-research east-africa-key-trends-observations/

Cloete N., \& Maassen, P. (2015). Roles of universities and the African context. In N. Cloete, P. Maassen and T. Bailey (Eds.), Knowledge Production and Contradictory 
Functions in African Higher Education. Cape Town: African Minds.

Degefa, D. (2015). Social Scientists' Understanding of Academic Freedom in Addis Ababa University, Ethiopia: A Descriptive Analysis. Higher Education for the Future, 2(1), $2-18$.

Ethiopian Education Strategy Centre (ESC). (2015). University Leadership and Management Capacity Development Project (ULMCD): Project Final Report. Addis Ababa: ESC. Federal Democratic Republic of Ethiopia (FDRE). (2003a). Higher Education Proclamation No. 351/2003. Addis Ababa: Negarit Gazeta.

Federal Democratic Republic of Ethiopia (FDRE). (2003b). Education Cost Sharing, Regulation No. 91/2003. Addis Ababa: Negarit Gazeta.

Federal Democratic Republic of Ethiopia (FDRE). (2009). Higher Education Proclamation No. 650/2009. Addis Ababa: Negarit Gazeta.

Federal Democratic Republic of Ethiopia (FDRE). (2012).Science Technology and Innovation Policy. Addis Ababa: FDRE.

Gebremariam, T. (2010). Graduate studies and research at Addis Ababa University: Past and Present. Addis Ababa: LESAN Printing Press.

Gulliksen, A., \& Audensen, E. (2013). Report on Recognition of Higher Education in Eritrea and Ethiopia: A Study Trip to Eritrea and Ethiopia in October 2012. NOKUTs utredninger og analyser.

Gurmessa, Z. B., \& Bayissa, J. T (2015). Pay and Performance in Ethiopian Higher Education: Implications Towards Staff Motivation And Engagement. European Journal of Business and Management, 7(7), 328-339.

Hayward, F. M., \& Ncayiyana, D. J. (2014). Confronting the challenges of graduate education in Sub-Saharan Africa and prospects for the future. International Journal of African Higher Education, 1(1), 173-216. 
Ishengoma, J.M. (2016). North-South research collaborations and their impact on capacity building: A Southern perspective. In Tor Halvorsen and Jorun Nossum (Eds.) NorthSouth Knowledge Networks: Towards equitable collaboration between academics, donors and universities (pp. 149-186), Cape Town: African Minds.

Jowi, J. O. (2009). Internationalization of higher education in Africa: Developments, emerging trends, issues and policy implications. Higher Education Policy, 22(3), 263281.

Jowi, J.O. (2012). Africa responds to internationalization: Redefining the terms of engagement between scholars worldwide. SARUA Leadership Dialogue Series, 4(2): 49-58.

Jowi, J. O., Knight, J., \& Sehoole, C. (2013). Internationalisation of African Higher Education. In C. Sehoole \& J. Knight (Eds.), Internationalisation of African Higher Education-Towards Achieving the MDGs (pp.11-31). Rotterdam: Sense Publishers.

Jowi, J.O. \& Obamba, M. (2011). Research and innovation management: Comparative analysis of Ghana, Kenya and Uganda. Draft Report, Paris: OECD.

Kahsay, M.N. (2015). Doctoral (PhD) Education in Ethiopia: Status, opportunities and perils. A paper presented at the International Conference on Doctoral Education, 24-26 March 2015, Orlando, Florida, USA. Available at:

\section{http://education.ucf.edu/reg/docs/ICDE2015}

Kebede, M. (2010). Comparing Traditional and Modern Education: the Decentring of Ethiopia. In Paulos Milkias \& Messay Kebede (Eds.), Education, Politics, and Social Change in Ethiopia (pp. 25-37). Los Angeles: Tsehai Publishers.

Kitaw, D. (2006).Towards Solving Existing Industrial Problems. Conference on Launching a Program to Transforming University-Industry-Government Relations in Ethiopia. Addis Ababa: United Nations Conference Center. 
Lestrade, V. (2012, February 19). Ethiopia: Gender disparity in higher education. University World News, African Edition, Issue No. 89, from http://www.universityworldnews. com/article.php?story=20120219080946487

Mamo, F. P. (2015). Revenue generation strategies in Sub-Saharan African Universities. Enschede: CHEPS.

Maassen, P. (2015, March 06). Research Productivity at flagship African Universities. http://www.universityworldnews.com/article.php?story=20150226083557823

Melese, W. (2012). Research-teaching link in higher education institutions of Ethiopia: the case of Jimma University, Basic Research Journal of Education Research and Review, $1(6), 85-89$.

Mekonnen, D. (2005). Continuing education at Addis Ababa University. In the proceeding of the symposium on adult education and development (pp. 224-227). Addis Ababa, Ethiopia: Goethe Institute, Geberekirsto Desta Center.

Ministry of Education (MOE). (2008). National Adult Education Strategy. The Federal Democratic Republic of Ethiopia, Addis Ababa: Ministry of Education.

Ministry of Education (MOE). (2010). Education Sector Development Program (ESDP IV): Program Action Plan. Addis Ababa: Ministry of Education.

Ministry of Education (MOE). (2015). Education Sector Development Program V (ESDP V):

Program Action Plan. Addis Ababa: Ministry of Education.

Ministry of Education (MOE). (2017). Education Statistics Annual Abstracts (2015/2016). Addis Ababa: Ministry of Education.

Molla, T. (2013). Higher education policy reform in Ethiopia: the representation of the problem of gender inequality, Higher Education Policy, 26 (2), 193-215.

Molla, T. (2014). Knowledge aid as instrument of regulation: World Bank's non-lending higher education support for Ethiopia, Comparative Education, 50 (2), 229- 
248.

Molla, T., \& Gale, T. (2015). Inequality in Ethiopian higher education: Reframing the problem as capability deprivation. Discourse: Studies in the Cultural Politics of Education, 36 (3), 383-397.

Molla, T., \& Cuthbert, D. (2016). In pursuit of the African PhD: A critical survey of emergent policy issues in select sub-Saharan African nations, Ethiopia, Ghana and South

Africa. Policy Futures in Education, 14 (6), 635-654.

Ng'ethe, N., Subotzky, G., \& Afeti, G. (2008). Differentiation and articulation in tertiary education systems: A study of twelve African countries (No. 145). Washington, DC: World Bank Publications.

O'Keeffe, P. (2016). The role of Ethiopia's public universities in achieving the United Nations Sustainable Development Goals, International Review of Education, 62 (6), 791-813.

Rayner, P., \& Ashcroft, K. (2012). Ethiopian higher education: Expansion, dilemmas and quality. World Education News and Reviews, 1 June 2011 [online]. Retrieved 23 January 2015 from http://wenr. wes.org/2011/06/wenr-june-2011-feature/.

Reisberg, L., \& Rumbley, L. (2015). Ethiopia: The dilemmas of expansion. International Higher Education, 58, 23-24.

Saint, W. (2004). Higher education in Ethiopia: the vision and its challenges, Journal of Higher Education in Africa, 2 (3), 83-113.

Semela, T. \& Amadi, E. C. (2010). Adult and Continuing Education in Post-Secondary Institutions in Ethiopia: Policy, Practice and Challenges, A Multidisciplinary International Journal on Sustainable Development (Adult and Continuing Education, 6(4), 1-39. 
Semela, T., \& Ayalew, E. (2008). Ethiopia. African Higher Education: The International Dimension. Accra: Center for International Higher Education (CIHE), Boston College, USA and Association of African Universities (AAU), 159-207.

Semela, T. (2011a). Breakneck expansion and quality assurance in Ethiopian higher education: ideological rationales and economic impediments, Higher Education Policy, $24,399-425$.

Semela, T. (2011b). Vulnerability to brain-drain among academics in institutions of higher learning in Ethiopia, Asian Social Science, 7 (1), 3-16.

Semela, T., \& Ayalew, E. (2008). Ethiopia. In Damtew Teferra \& Jane Knight (Eds.), Higher education in Africa: The international dimension (pp. 159-207).Boston: Center for International Higher Education, Boston College and the Association of African Universities.

Sidelil, L. T. (2015). The Ethiopian Higher Education Equity Policy and its Flaws. Bahir Dar Journal of Education, 15(2), Retrieved from:

\section{http://journals.bdu.edu.et/index.php/bje/article/view/16/42}

Seyoum, T. (1995). A project in Ethiopian traditional education. In: IER (Ed.), Proceedings of the national workshop on strengthening educational research (pp. 31-36). Addis Ababa: Addis Ababa University.

Taylor, J. (2006) Managing the Unmanageable. The Management of Research in Research Universities. Higher education Management and policy, 8 (2), 1-25.

Teferra, D., \& Altbach, P. G. (2004). African higher education: Challenges for the $21^{\text {st }}$ century. Higher education, 47(1), 21-50.

Teferra, D. (2013). Introduction. In Damtew Teferra (Ed.) Funding Higher Education in Sub Saharan Africa (pp. 1-12), London: Palgrave Macmillan.

Teferra, D. (2017). African Flagship Universities in the Era of "Massification”. In Damtew 
Teferra (Ed.), Flagship Universities in Africa (pp. 1-16). Cham: Palgrave Macmillan.

Teferra, D. (2007). Building Research Capacity in Ethiopian Universities: The Realities and Challenges . Speech delivered at the Conference on Higher Education in Ethiopia: Future Challenges, December 15-16. Addis Ababa.

Tamrat, W. (2015). Internationalization of Higher Education in Ethiopia: Evidence from Public and Private Institutions. In Proceedings of the 13th International Conference on Private Higher Education in Africa. St. Mary’s University: Addis Ababa.

Tamrat, W. \& Teferra, D. (2018). Disparities and Parallels in Internationalization: The Ethiopian Experience, International Higher Education, 92 (17-19).

Tamrat, W. (2018, March 09). Disability in Higher Education: From Policy to Practice. University World News.

http://www.universityworldnews.com/article.php?story=20180307105907347

Tamrat,W. (2018, February 09). Graduate responsibility: Whose Responsibility?University World News.

http://www.universityworldnews.com/article.php?story=20180206100000225

Tessema, K.A. (2009). The unfolding trends and consequences of expanding higher education in Ethiopia: massive universities, massive challenges, Higher Education Quarterly, 63 (1), 29-45.

Transitional Government of Ethiopia (TGE). (1994). Education and Training Policy. EEP -86: Addis Ababa.

Trow, M. (2007). Reflections on the Transition from Elite to Mass to Universal Access: Forms and Phases of Higher Education in Modern Societies since WWII. Springer International Handbook of Education, 18, 243-280.

Van Deuren, R., Kahsu, T., Mohammed, S., \& Woldie, W. (2016). Ethiopian new public 
universities: Achievements, challenges and illustrative case studies. Quality Assurance in Education, 24(2), 158-172.

Wagaw, T. (1990). The Development of Higher Education and Social Change: The Ethiopian Experience. East Lansing: Michigan University Press.

Wagaw, T. (1979). Education in Ethiopia: Prospect and Retrospect. Ann Arbour: University of Michigan Press.

Waweru, K.M. \& Abate, S. (2013).Revenue Diversification and Resource Utilisation in Ethiopian Universities. In D. Teferra (Ed.), funding higher education in Sub-Saharan Africa (pp. 71-97). London: Palgrave Macmillan.

Woldegiyorgis, A. A. (2014). The indelible footmarks of the World Bank in the higher education of the developing world: The case of Ethiopia. International Journal of Research Studies in Education, 3 (3), 93-106.

Woldeyes, M. M. (2016). Breaking Higher Education's Iron Triangle through Distance Education: The Case of IGNOU in Addis Ababa, Ethiopia. International Journal of Education, 8 (3), 31-49.

Wondimu, H. (2003). Ethiopia. In D. Teferra, \& P.G Altbach. (Eds.), African Higher Education: An International Reference Handbook (pp. 316-325). Bloomington: Indiana University Press.

Yigezu, M. (2013). Funding higher education in Ethiopia: Modalities, challenges, opportunities, and prospects. In D. Teferra (Ed.), funding higher education in SubSaharan Africa (pp. 38-70). London: Palgrave Macmillan.

Yirdaw, A. (2016). Quality of education in private higher institutions in Ethiopia: The role of governance. SAGE Open, 6 (1), 1-12.

Yizengaw, T. (2003). Transformations in higher education: Experiences with reform and expansion in Ethiopian higher education system. In Keynote speech 
presented at the Africa regional training conference entitled Improving Tertiary

Education in Sub Saharan Africa: Things that Work (pp. 23-25).

Yizengaw, T. (2007). The Ethiopian higher education: Creating space for reform. St. Mary's UC printing press: Addis Ababa. 